カル $\mathrm{RO}_{2}$. の数の, 添加 $\mathrm{Cu}^{2+}$ 量汇対する相対的大さの大小に より説明される。たとえば実験 1035 では $4.0 \mathrm{M} \% / \mathrm{hr}$ の酸化速 度で酸化が進行しているところに $\mathrm{Cu}^{2+}$ を加えたのであるから， $\mathrm{Cu}^{2+}$ 添加洺数存在している $\mathrm{RO}_{2}$. の一部を不活性化したにと どまり，酸化を停止させるには至らなからたのであるう。

これから考えると，第 3 種カチオンは本質的炕は第 2 種に包含
されるべきすのである。

本報交は日化第 8 年会 $(1955,4$ 月) 飞その大半を発表したすの

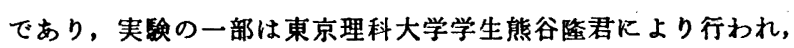
原料 $p$-キシンンは帝国人絹株式会社より寄贈され，研究費の一 部は学振第 116 委員会研究費によった。愿く感謝の意を表す。

\title{
（258） 高粐不飽和アルコールとオソンとの反底について
}

\author{
(昭和 30 年 4 月 7 日受理)
}

和 泉*

\section{1. まえがき}

著者はさきに1),ツバキ油扰よびオリーブ油をそれぞれ強極性 無水溶媒である水酶酸の中でオン゙ン分解して，反応機構について 检䞑を加えたが，本報ではこれらの方法に準じて，高叙不飽和了 ルコールのオン゙ン分解を行った結果を報告する。低級アルコール に対するオジンの反応については Fischer?) の報告があり，これ によればアルコール基は酸化され酸拈よびアルデヒドを生じる。 一方 Helferich ら³はオレイルアルコールを氷酢酸に溶かし室温 でオジン化したのち，エーテル，水，覀銍末を加え加熱してオン゙ナ イドを分解し, 分解生成物中から 9-オキシノニルアルデヒド, 怙よびノニルアルデヒドを得ている。著者汢高䄲不飽和アルコー ルを承酢酸に溶かし, 室温 (約 $22^{\circ} \mathrm{C}$ ) 打よび劣沸温度 (約 $118^{\circ} \mathrm{C}$ ) でオゾン化酸素を反応させたのち，そのまま反応液を劣沸してオ ゾナイドを分解し，オン゙ン反応温度，オゾン反応量および分解生 成物の組成の関係をしらべ, 反応機構について二, 三の検討を加 えた。

\section{2. 試料および実験操作}

使用した高鈒不飽和アルコールは市眅のオレイルアルコール で,このものはヨウ素価 (Wijs 法) 94.13, 酸価 1.44, ケン化 価 2.77, ヒドロキシル価（無水酰酸・ピリジン法） 206 を示し, また常圧で 330〜333ㄷ C の主留分を約 $98 \mathrm{wt} \%$ 含有し，オレイル アルコール（計算值：ヨウ素価 94.7, 七ドロキシル価 209）の他 に少量の不純物を含むるのと認めた。オジン発生装置は既報1)の あのと同じであるが，オジン反応器は，従来使用してきた反応 筒り の代わりに，約 $200 \mathrm{cc}$ 容の三つロフラスコを用い，その中 央の口に僈流冷却器をつけ，これを通して排ガスを逃がし，ま た，別のロからオゾン化酸素をガラス管でフラスコの底に導き， 残りのロはコルク栓で閉じた。オゾン化酸菜中のオゾンの荟度は 既報の方法1)で, 試料と反応させる直前に毎回測定し，反応オジ

* 工業技術院名古屋工業技術試験所：名古屋市北区.

1) 和泉, 工化 54, 546 (1951), 和泉, 工化 57, 499 (1954).

2) F. G. Fischer, Ann. 476, 233 (1930).

3) B. Helferich, W. Schäfer, Ber. 57, 1913 (1924). [Houben-Weyl, Methoden der Organischen Chemie VII(1), 344 (1954)].
ン量を知る目安とした。いずれの場合も流速 $450 \mathrm{cc} / \mathrm{min}$ で, お よそ $4 \mathrm{wt} \%$ のオジン濃度であった。試料は毎回約 $5 \mathrm{~g}$ を記三 つロフラスコに精称し，承醀酸(過マンガン酸カリ精慗，bp 116〜 $\left.118^{\circ} \mathrm{C}\right) 50 \mathrm{cc}$ を加えて溶液としたのち常温でまたは直火で加熱し て劣沸させながら，それぞれオジン化酸素を吹き込んで反応させ た。排ガスを $10 \%$ ヨ.ウ化カリウム水溶液中に導いて，排ガス中 に残存していた未反応のオジンの量を、 ヨウ化カリウムから分解 析出したヨウ素の呈色度でくらべた。三つロフラスコを反応容器 とした場合には従来の反応筒を用いた場合と異なって, オジンの 吸収はやや劣った。いずれの場合にも，一定の試料に対してオン゙ ン化酸素を $10 ， 30 ， 50 ， 70$ および 90 分間ずつ反応させたのち， ただちに 1 時間煮沸し，オゾナイドを分解】した。室温に泠却し てから，エーテル $200 \mathrm{cc}$ を加えて分液漏斗俰し，水 $300 \mathrm{cc} す$ つで数回水洗をくり返し，洗液がメチルオレンジで中性になって から，エーテル溶液を別け，脱水ボウ硝で脱水したのちェーテル を除去して，収量，酸価，カルボニル価（塩酸ヒドロキシルアミ ン法さ)，ケン化価などを測定した。上記操作中試料を氷酰酸中で 煮沸しているので，常識的にアルコール基の醁酸エステル化が起 ったるのと推定し，これを確かめるために樲料 $5 \mathrm{~g}$ を氷醀酸 50 cc に溶かして僄流堂沸し, 前と同様にエーテル抽出, 水洗, 脱 水, 脱エーテルののち, 酸価, ケン化価を測定し, 劣沸時間と土 ステル生成との関係を求めた。また，オゾン化酸素中の酸素と， オゾン化しない酸素とは化学的性筫を異にするよ5であるがの， オゾン化酸素の代わりに酸素を使用した以外は前記のオン゙ン化の 操作と全く同様にして，办酶酸中に打ける試料と酸素々の反応性 を明らかにして比較対照した。またこの場合にも，Fischer²)の い5よラに, アルコール基がオゾンと反応してカルボキシル基に なる結果生成するであろらと想像されるアゼライン酸の存在の有 無をしらべるために，井上らの方法6ににしたがってオヴン分解生 成物を常法により $1.5 \%$ 硫酸メタノール溶液と劣沸してメチル エステル化したのち，ヒドロキシルアミン塩酸塩（特級品）と水 酸化カリウムのアルコール溶液と煮沸してヒドロキザム酸塩に变

4) 工化 $42,40 \mathrm{~A}$ (1939).

5) E. Briner, et al., Helv. Chim. Acta 14, 794(1931), Chem. Abst. 25, 4867 (1931).

6) 井上, 野田, 農化 24, 291 (1951): 
之, 希塩酸アルコール液で微酸性にして遊離のヒドロキザム酸に 導き, 水飽和のイソアミルアルコールを展開溶媒とした恒温 (30 ${ }^{\circ}$ C) 下降法のペーパークロマトケラフ分析を行った。

\section{3. 実験結果および考察}

第 1 表は室温 $\left(22 \sim 23^{\circ} \mathrm{C}\right)$ でオゾン化酸素を反応させた場合で,

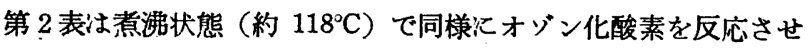
た場合である。オゾン化後, オゾナイドを分解するための煮沸時 間は前記したよ5に，すべて 1 時間であるから第 1 表では総煮沸 時間はすべて 1 時間であるが, 第 2 表の場合は, オゾン化中る煮 沸しているので, 総劣沸時間は両者の和である。エステル価はヶ ン化価と酸価との差である。

\begin{tabular}{|c|c|c|c|c|c|c|}
\hline & & 第 & 1 & 表 & & \\
\hline $\begin{array}{l}\text { 試料 } \\
\text { (g) }\end{array}$ & $\begin{array}{l}\text { オジン } \\
\text { 反応時間 } \\
\text { (min) }\end{array}$ & $\begin{array}{c}\text { 総煮沸 } \\
\text { 時 間 } \\
\text { (hr) }\end{array}$ & $\begin{array}{l}\text { 収量 } \\
\text { (g) }\end{array}$ & 酸 価 & $\begin{array}{l}\text { カル } \\
\text { ボ二 } \\
\text { ル価 }\end{array}$ & $\begin{array}{l}\text { エス } \\
\text { テル } \\
\text { 価 }\end{array}$ \\
\hline 5.02 & 10 & 1 & 6.15 & 12.6 & 72.6 & 167 \\
\hline 5.01 & 30 & " & 5.73 & 157 & 103 & 153 \\
\hline$"$ & $50^{-}$ & " & 5.69 & 175 & 80.5 & 154 \\
\hline " & 70 & " & 5.48 & 187 & 73.2 & 145 \\
\hline$\prime \prime$ & 90 & " & 5.83 & 178 & 66.7 & 161 \\
\hline
\end{tabular}

\begin{tabular}{|c|c|c|c|c|c|c|}
\hline & & 第 & 2 & 表 & & \\
\hline $\begin{array}{l}\text { 試料 } \\
\text { (g) }\end{array}$ & $\begin{array}{l}\text { オゾンัン } \\
\text { 反応時間 } \\
\text { (min) }\end{array}$ & $\begin{array}{l}\text { 総著沸 } \\
\text { 時 間 } \\
\text { (min) }\end{array}$ & $\begin{array}{l}\text { 収量 } \\
\text { (g) }\end{array}$ & 酸 価 & $\begin{array}{l}\text { カル } \\
\text { ボ二 } \\
\text { ル価 }\end{array}$ & $\begin{array}{l}\text { エス } \\
\text { テル } \\
\text { 価 }\end{array}$ \\
\hline 5.01 & 10 & 70 & 5.89 & 15.8 & 69.1 & 183 \\
\hline 5.02 & 30 & 90 & 6.12 & 88.9 & 78.6 & 203 \\
\hline 5.01 & 50 & 110 & 6.05 & 117 & 51.9 & 204 \\
\hline 5.02 & 70 & 130 & 5.84 & 138 & 32.1 & 208 \\
\hline 5.01 & 90 & 150 & 5.98 & 146. & 32.3 & 214 \\
\hline
\end{tabular}

第 1 表および第 2 表沈いて，オジン濃度から計算するといず れもオゾン反応時間が 30 分付近で, 試料溶液に導入されたオり゙ ンの量恃試料のエチレン結合の当量に達する。酸価とカルボニル 価との相対関係はオゾン化の初期㹸あってはいずれも後者が前者 よりる著しく大きい値を示したが，オゾン化が高度に達するとそ の関係は逆になった。この事実は，オリーブ油をオゾン化したと きに現われた変化1) と酷似した。第 2 表の酸価とカルボニル価と の和は第 1 表のそれとくらべると一般に低い。エステル価は逆に 第 2 表の方が第 1 表より 高い。試料と氷酢酸とを煮沸して竟沸 時間とエステル生成との関係を求めた結果が第 3 表である。

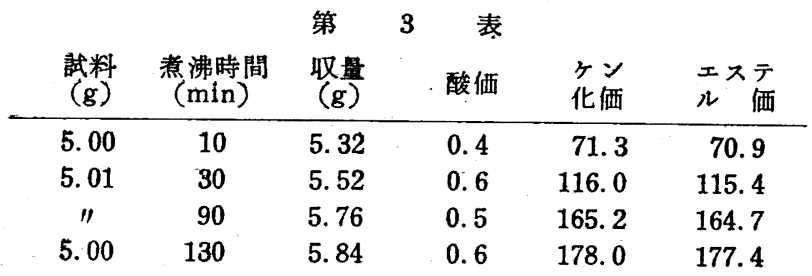

オゾン化酸素の代わりに酸素を用い前記のオゾン化の場合と全 く同じ操作によった対照実験結果を第 4 表に示した。

\begin{tabular}{|c|c|c|c|c|c|c|}
\hline & & 第 & 4 & 春 & & \\
\hline $\begin{array}{l}\text { 試料 } \\
\text { (g) }\end{array}$ & $\begin{array}{l}\text { 酸素度 } \\
\text { 底時間 } \\
(\mathrm{min})\end{array}$ & $\begin{array}{l}\text { 総堂沸 } \\
\text { 時 間 } \\
\text { (min) }\end{array}$ & $\begin{array}{l}\text { 収量 } \\
\text { (g) }\end{array}$ & 酸価 & $\begin{array}{l}\text { ケン } \\
\text { 化価 }\end{array}$ & $\begin{array}{l}\text { エス } \\
\text { テル } \\
\text { 価 }\end{array}$ \\
\hline 5.02 & 10 & 70 & 5.75 & 1.4 & 163 & 162 \\
\hline$" 1$ & 30 & 90 & 5.79 & 1.8 & 165 & 163 \\
\hline 5. 01 & 50 & 110 & 5.75 & 2.3 & 172 & 170 \\
\hline 5.02 & 70 & 130 & 5.79 & 3.5 & 178 & 175 \\
\hline
\end{tabular}

第 1，3，4 表のエステル価恃間的て見てほぼ同様な値を示し たのに対し，第 2 表のエステル価は第 $1,3,4$ 表のそれにくらぺ て一般に相当に高い值を示した。このエステル価が高いことと第 2 表の酸価とカルボニル洒との和が低いこととは劣沸状態でオり゙ ン化酸素を反応させるとオゾナイドの生成, ならびにオゾナイド

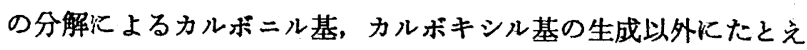
ばオキシ酸のような副反応物が多くできて,これが氷酢酸によっ てェステル化された結果ではないかと想像した。

第 5 表に，第 1 表および第 2 表の中でオゾン反応時間を 70 分 としたそれぞれの分解生成物のヒドロキザム酸誘導体について， ペーパークロマトグラフ分析を行い, 塩化鉄アルコール液噴墅に よって発色させた色斑の $R_{\boldsymbol{f}}$ 值と，酢酸メチル（1 叙品）とアゼ

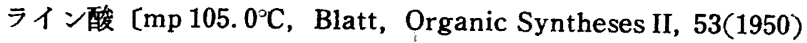
にしたがってつくったるとから前記と同様の方法で, それぞれの ヒドロキザム酸液をつくり, 前と同様にして求めた $R_{f}$ 值とを示 した。 $30^{\circ} \mathrm{C}, 6$ 時間の展開時間で溶媒の移動距離俚䄪 $20 \mathrm{~cm}$ 。口 柾は東洋濾紙 No. 50 (ペーパークロマトグラフ用) $2 \mathrm{~cm} \times 40 \mathrm{~cm}$ である。

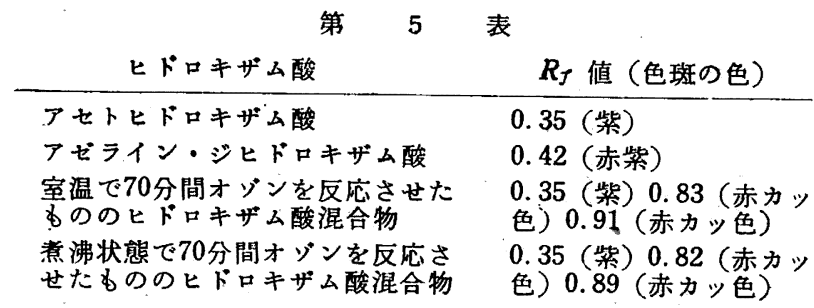

第 5 表の結果から，オゾン分解生成物中にアゼライン酸が著舅 に存在するとは認めえなかった。

\section{4.むす ひ}

無水強極性溶媒 (水醀酸). 中に打ける高釉不飽和アルコール （オレイルアルコールの他に少量の不純物を含さ）と，オゾン化 酸素との反応について検㑏した。アルコール氷醀酸溶液にオジン 化酸素を室温ならびに煮沸状態いずれの条件で反応させても，反 応物をそのまま惹沸してオゾナイドを分解して得た生成物のカル ボニル価と酸価との関係はオゾン反応時間が短いときは前者が後 者よりる大きく、オゾン反応時間が長くなると逆に後者の方が大 きくなった。この变化の傾向は既報1)のオリーブ油のオゾン分解 のとき見られた結果と酭似した。

オン゙ン化酸素を 70 分間反応させて得た 2 種の分解生成物につ いて, 水飽和イソアミルアルコールを展開溶媒として恒温 $\left(30^{\circ} \mathrm{C}\right)$ 下降法によるペーパークロマトグラフ分析を行った結果, アゼラ イン酸が顥著に生成しているとは認めえず，Fischer ${ }^{2}$ )の，低剩 アルコールがオゾンによって酸および少量のアルデヒドを生成し たとの報告から想像した高叙アルコール基のカルボキシル基への 酸化は著しいるのでないるのと認めた。

オゾン化酸素を煮沸状態で反応させたときは室温で反応させた ときよりあ分解生成物のエステル価が大きな值を示した。これは 前者の場合, たとえばオキシ酸のような副反応物ができてこれが 氷酢酸によってェステル化された結果ではないかと想像した。

（昭和 29 年 11 月, 日化油脂討論会講演)

御想第な御指道をいただいた恩師西沢恭助博士に菲んで感謝申 し上げる。また実験に協力された山田裕技官に深謝する。 